\title{
Systematic Review with Meta-Analyses of Natural Products in the Treatment of Recurrent Aphthous Stomatitis
}

\author{
Katherine S Phillips, DDS, DABDSM ${ }^{1}$, Wallace C Carrillo Medina, DMD ${ }^{1}$, Joeseph M Potter, BA, DDS ${ }^{1}$, \\ Kamal Al-Eryani, DDS, $P h D^{2}$ and Reyes Enciso, $P h D^{3^{*}}$
}

\author{
${ }^{1}$ Advanced Graduate, Master of Science Program in Orofacial Pain and Oral Medicine, Herman Ostrow \\ School of Dentistry of USC, USA \\ ${ }^{2}$ Assistant Professor, Division of Periodontology, Diagnostic Sciences \& Dental Hygiene, Herman Ostrow \\ School of Dentistry of USC, USA \\ ${ }^{3}$ Associate Professor, Division of Dental Public Health and Pediatric Dentistry, Herman Ostrow School of \\ Dentistry of USC, USA
}

*Corresponding author: Reyes Enciso, PhD, Associate Professor, Instructional, Division of Dental Public Health and Pediatric Dentistry, Herman Ostrow School of Dentistry of USC, 925 West 34th St, Room 4268, Los Angeles, California, USA, Fax: (213)-740-8815

\section{Abstract}

Objective: Conduct a systematic review and meta-analysis of natural products in the treatment of recurrent aphthous stomatitis (RAS) and their effect on the size and pain levels compared with placebos.

Study design: Randomized placebo-controlled trials were identified up to January 2019 in PubMed, EMBASE, Web of Science and Cochrane Library. Cochrane Risk of Bias tool was used to assess the risk of bias.

Results: The search yielded 248 unduplicated references. After evaluation, 11 studies with 694 subjects with RAS were included. One was considered low risk of bias, two were considered high risk and eight were considered unclear risk. In a meta-analysis, natural products provided a statistically significant reduction in ulcer size of about -1.74 $\mathrm{mm}$ compared to placebo $(95 \% \mathrm{Cl}=-3.151$ to $-0.327 ; \mathrm{p}=$ 0.016 ); also pain intensity improved moderately with an effect size (standardized difference in means) of -0.79 (95\% $\mathrm{Cl}=-1.447$ to $-0.141 ; \mathrm{p}=0.017$ ). Quality of evidence was moderate due to unclear/high risk of bias for ulcer size and pain intensity. The group using natural products were 2.556 times as likely to improve than placebo subjects at 3-4 days. Similar results after 5-7 days with low quality of evidence.

Conclusions: The selected group of 11 natural products included in this systematic review seem to reduce pain intensity and lesion size in RAS patients with low to moderate quality of evidence. However, due to high heterogeneity and unclear/high risk of bias, the results are inconclusive.
\end{abstract}

\section{Keywords}

Natural products, Recurrent aphthous stomatitis (RAS), Plantbased interventions, Honey, Herbal supplement, Systematic review, Meta-analysis, Randomized controlled trial, Visual analog scale

\section{Abbreviations}

RAS: Recurrent Aphthous Stomatitis; Cl: Confidence Interval; PRISMA: Preferred Reporting Items for Systematic Reviews and Meta-analyses; PICO: Patient Intervention Comparison Outcome; RCTs: Randomized Controlled Trials; OHIP: Oral Health Impact Profile; VAS: Visual Analog Scale; El: Efficacy Index; RR: Risk Ratios; GRADE: Grades of Recommendation Assessment Development and Evaluation; SDM: Standardized Difference in Means

\section{Introduction}

Recurrent aphthous stomatitis (RAS) is a disorder characterized by recurring ulcers confined to the oral mucosa in patients with no other signs of disease. RAS affects approximately $20 \%$ of the general population [1]. It is the most common ulcerative disease of the oral mucosa [2]. It is more common in children with a prevalence of 39\% [3]. Prevalence decreases with advancing age and increases with higher socioeconomic status and female gender [4]. A prodromal period of 2-48

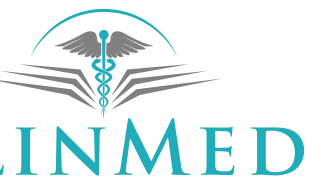

INTERNATIONAL LIBRARY

Citation: Phillips KS, Medina WCC, Potter JM, Al-Eryani K, Enciso R (2019) Systematic Review with Meta-Analyses of Natural Products in the Treatment of Recurrent Aphthous Stomatitis. Int J Oral Dent Health 5:103. doi.org/10.23937/2469-5734/1510103

Accepted: November 25, 2019: Published: November 27, 2019

Copyright: (c) 2019 Phillips KS, et al. This is an open-access article distributed under the terms of the Creative Commons Attribution License, which permits unrestricted use, distribution, and reproduction in any medium, provided the original author and source are credited. 
hours precedes the ulceration [4]. During the prodromal period, patients may experience tingling or burning in the area where the ulceration develops. The ulcers are round and shallow with an erythematous border and white, yellow or gray pseudo membrane. The lesions occur most commonly in non-keratinized oral mucosa, such as the buccal mucosa, but may also occur on keratinized tissue like the hard palate [2-5]. The course of the lesion healing is variable, and the lesions may last days or weeks before healing is complete. The lesions can be quite painful and affect nutrition, speech and oral hygiene [3].

Other diseases such as herpes stomatitis, Behçet's disease, Crohn's Disease and ulcerative colitis may be considered in the differential diagnosis of intraoral ulcerations, but are different etiological entities than RAS. The precise etiology of RAS is unknown. There may be a combination of contributory factors that lead to development of RAS in each individual patient. Regardless, the etiology of RAS is multi-factorial and may be related to trauma, nutritional deficiency, allergy, altered immune response and stress $[2,3]$. There is also a hereditary component; children whose parents both experience RAS exhibit a $90 \%$ prevalence of the condition $[3,6]$.

A number of treatments for RAS have been evaluated, including use of topical analgesic anti-inflammatory drugs, local anesthetics, topical antibiotics, antiseptics and topical steroids [1]. Although topical medications can be helpful, not every patient will experience satisfactory response to topical interventions. Several systemic medications have been considered for management of RAS including corticosteroids, dapsone, thalidomide and colchicine, among others $[1,2,4]$. Because of the possible adverse effects from systemic medications, herbal supplements and natural products have been advocated as an alternate form of treatment.

There is a growing interest among patients, clinicians and researchers as to the viability of 'natural products' as appropriate treatment options due to the perceived lack of side effects and the variability of response to topical medications. In this systematic review, 'natural products' are defined as compounds that are derived from natural sources such as plants, animals or micro-organisms [7]. A total of eleven plant-based interventions and honey (herbal supplements or natural products) have been studied in randomized controlled trials against a placebo (Table 1). The objective of this study was to conduct a systematic review and meta-analysis of natural products in the treatment of RAS and their effect on the size of RAS lesions and the pain levels compared with placebos.

\section{Methods and Materials}

This systematic review adhered to the Preferred reporting items for systematic reviews and meta-analyses (PRISMA) statement [8].

\section{Inclusion and exclusion criteria}

The PICO (Patient, Intervention, Comparison, Outcome) question was, in adult patients with recurrent aphthous stomatitis, do natural products (plantbased or animal-based) reduce ulcer size and pain intensity compared to placebo. Studies were limited to Randomized controlled trials (RCTs) on the efficacy of natural products to treat recurrent aphthous stomatitis in adults compared to placebo [9-19]. Synthetic supplements such as vitamins (including LongoVitala mix of vitamins and a variety of herbs) were exclud-

Table 1: Mechanism of action, interactions and adverse reactions of the interventions included in this systematic review.

\begin{tabular}{|c|c|c|c|c|}
\hline Intervention & $\begin{array}{l}\text { Common } \\
\text { names }\end{array}$ & $\begin{array}{l}\text { Mechanism of } \\
\text { action }\end{array}$ & Interactions (Lexicomp) & Adverse reactions (Lexicomp) \\
\hline Satureja khuzistanica [9] & Mint & $\begin{array}{l}\text { This plant has } \\
\text { antispasmodic, } \\
\text { antidiarrheal, } \\
\text { antioxidant, anti- } \\
\text { inflammatory, and } \\
\text { chemotherapeutic } \\
\text { properties. }\end{array}$ & None well documented. & $\begin{array}{l}\text { The oil is strongly irritating in animal } \\
\text { skin models, but is not phototoxic. }\end{array}$ \\
\hline $\begin{array}{l}\text { Proaftol ( } 25 \% \text { propolis, } \\
\text { benzocaine, sage, } \\
\text { peppermint, aniseed, } \\
\text { menthol) [10] }\end{array}$ & $\begin{array}{l}\text { Propolis } \\
\text { (bee glue) }\end{array}$ & $\begin{array}{l}\text { This mixture is } \\
\text { an antibiotic with } \\
\text { anti-inflammatory } \\
\text { and anti-oxidant } \\
\text { properties. }\end{array}$ & None well documented. & $\begin{array}{l}\text { Allergic reactions with skin and } \\
\text { mucous membrane irritations have } \\
\text { been reported. Sensitization to } \\
\text { propolis, long recognized by apiary } \\
\text { workers, has also been reported. }\end{array}$ \\
\hline Myrtle [11] & Periwinkle & $\begin{array}{l}\text { Myrtle has anti- } \\
\text { hyperglycemic, } \\
\text { antibacterial } \\
\text { and analgesic } \\
\text { properties. }\end{array}$ & $\begin{array}{l}\text { An in vitro study } \\
\text { evaluated the effect of } \\
\text { periwinkle alkaloids on the } \\
\text { cytochrome (CYP) P450 } \\
\text { enzyme system, and } \\
\text { some isolated alkaloids } \\
\text { showed potent inhibition } \\
\text { of CYP2D6, but weak } \\
\text { activity against CYP3A4. }\end{array}$ & $\begin{array}{l}\text { Clinical information is lacking. Adverse } \\
\text { reactions are documented for vinca } \\
\text { alkaloids related to doses used in } \\
\text { chemotherapy. }\end{array}$ \\
\hline
\end{tabular}




\begin{tabular}{|c|c|c|c|}
\hline Aloe vera $[12,17]$ & $\begin{array}{l}\text { Aloe Vera is wound } \\
\text { healing, anti- } \\
\text { inflammatory, and } \\
\text { anti-infection agent. }\end{array}$ & $\begin{array}{l}\text { Hypoglycemic- } \\
\text { associated agents: } \\
\text { Herbs (hypoglycemic } \\
\text { properties) may enhance } \\
\text { the hypoglycemic effect of } \\
\text { hypoglycemic associated } \\
\text { agents. Monitor therapy. }\end{array}$ & $\begin{array}{l}\text { Except for dried latex, aloe is not } \\
\text { approved as an internal medication. } \\
\text { The external use of aloe has not } \\
\text { been associated with severe adverse } \\
\text { reactions; the majorities are relatively } \\
\text { mild and reversible upon cessation. } \\
\text { Reports of burning sensations } \\
\text { following topical application of aloe } \\
\text { gel to dermabraded skin have been } \\
\text { described. } \\
\text { Contact dermatitis from the related } \\
\text { Aloe arborescens has been reported. } \\
\text { Erythema, edema, urticaria, and } \\
\text { eczematous rash have also been } \\
\text { reported following } A \text {. vera application. }\end{array}$ \\
\hline Honey [13] & $\begin{array}{l}\text { Honey has anti- } \\
\text { infection and rapid } \\
\text { wound healing } \\
\text { properties. }\end{array}$ & $\begin{array}{l}\text { None well documented for } \\
\text { honey or bee pollen. Case } \\
\text { reports of hematuria due } \\
\text { to potentiation of warfarin } \\
\text { have been documented } \\
\text { with royal jelly. }\end{array}$ & $\begin{array}{l}\text { Allergic reactions may occur to } \\
\text { pollen in honey when ingested. } \\
\text { Attempts to hyposensitize patients } \\
\text { by administering bee pollen may } \\
\text { produce severe anaphylaxis and other } \\
\text { acute or chronic responses. Although } \\
\text { rare, bee pollen can cause serious, } \\
\text { sometimes fatal, adverse reactions. } \\
\text { Some case reports of acute hepatitis } \\
\text { and photosensitivity following ingestion } \\
\text { of bee pollen have been reported. In } \\
\text { many allergic patients, skin tests are } \\
\text { positive for royal jelly. Case reports } \\
\text { exist of allergy, acute exacerbation of } \\
\text { asthma, anaphylaxis, and death. }\end{array}$ \\
\hline Rosa damascene [14] & $\begin{array}{l}\text { Antioxidant, anti- } \\
\text { inflammatory, } \\
\text { and anti-bacterial } \\
\text { properties have } \\
\text { been reported for } \\
\text { this plant. }\end{array}$ & $\begin{array}{l}\text { Nausea, indigestion, } \\
\text { peptic ulcer, and } \\
\text { diarrhea are some of } \\
\text { the side-effects of these } \\
\text { treatments. }\end{array}$ & None well documented \\
\hline $\begin{array}{l}\text { 0.65\% Yunnan Baiyao } \\
{[16]}\end{array}$ & $\begin{array}{l}\text { This powder has } \\
\text { anti-hemorrhagic } \\
\text { hemostatic and } \\
\text { wound healing } \\
\text { properties. }\end{array}$ & None well documented & None well documented \\
\hline Myrrh [17] & $\begin{array}{l}\text { Myrrh has anti- } \\
\text { inflammatory and } \\
\text { wound healing } \\
\text { properties. }\end{array}$ & $\begin{array}{l}\text { Myrrh may interact } \\
\text { with warfarin and other } \\
\text { coumarin derivatives, } \\
\text { resulting in a reduction } \\
\text { in the international } \\
\text { normalized ratio (INR). }\end{array}$ & $\begin{array}{l}\text { Several cases of dermatitis have been } \\
\text { reported. }\end{array}$ \\
\hline Berberine [15] & $\begin{array}{l}\text { Berberine has } \\
\text { been shown to } \\
\text { have antimicrobial, } \\
\text { anti-inflammatory, } \\
\text { antitumor, and anti- } \\
\text { pyretic properties. }\end{array}$ & $\begin{array}{l}\text { Case reports are lacking; } \\
\text { however, barberry } \\
\text { exhibits anti-cytochrome } \\
\text { P450 3A4 (CYP3A4) } \\
\text { activity similar to that } \\
\text { of grapefruit. Caution } \\
\text { is warranted with } \\
\text { co-administration of } \\
\text { potentially toxic medicines } \\
\text { such as cyclosporine. }\end{array}$ & $\begin{array}{l}\text { 1. GI symptoms (eg, nausea, vomiting, } \\
\text { diarrhea), dizziness, and fainting have } \\
\text { been reported. } \\
\text { 2. Effects on the cardiovascular } \\
\text { system (eg, hypotension, decreased } \\
\text { heart rate) and decreased respiration } \\
\text { may occur with high dosages. The } \\
\text { German Commission E reports that } \\
\text { lower doses of berberine are well } \\
\text { tolerated. } \\
\text { 3. Hypersensitivity has been } \\
\text { documented. }\end{array}$ \\
\hline
\end{tabular}




\begin{tabular}{|l|l|l|l|}
\hline Camel thorn [18] & $\begin{array}{l}\text { Camel thorn has } \\
\text { been shown to } \\
\text { protect gastric } \\
\text { mucosa of rats } \\
\text { through its } \\
\text { inhibitory effects on } \\
\text { acid secretion. }\end{array}$ & None well documented & None well documented \\
\hline Pudilan keyanning [19] & $\begin{array}{l}\text { Anti-inflammatory, } \\
\text { anti-bacterial and } \\
\text { anti-viral properties. }\end{array}$ & None well documented & None well documented. \\
\hline
\end{tabular}

ed. Editorials, literature reviews, systematic reviews, case reports, animal studies, pilot studies, not randomized controlled trials and clinical guidelines were excluded. Reviews, systematic reviews and guidelines were scanned for relevant trials. Articles not available in English were also excluded (Table 1).

Outcomes: The primary outcomes of this systematic review were ulcer size in millimeters measured with a ruler or caliper, and pain intensity measured with various validated scales. Secondary outcomes included level of erythema and exudation, measured using a 4 point scale 0-3 (Erythema: 0-no erythema; 1-Light red/pink; 2-Red but not dark in color; 3-Very red, dark in color. Exudation: 0-no exudation; 1-Light exudation; 2-moderate; 3-heavy exudation, with pseudo membrane), based on the methods of Greer 1993 [20] with modifications by Liu, et al. [21].

The degree of hyperemia was also reported on a scale 0-3 as follows: 0-no hyperemia; 1-reddish; 2-deep red; 3-purplish red [19]. Another secondary outcome analyzed was the Efficacy index (EI) for ulcer size or pain, as defined by Meng, et al. [22] and Liu, et al. [16]. The El was evaluated on a 4-rank scale: 1 -Heal: $\mathrm{EI}=100 \%$; 2-Marked improvement: $100 \%>$ EI > 70\%; 3-Moderate improvement: 70\% > El $\geq 30 \%$; 4-No improvement: $\mathrm{EI}<$ $30 \%$. Review authors defined a significant improvement as patients with an EI $>70 \%$. Finally, time to complete healing in days was evaluated as well in addition to the Oral health impact profile (OHIP) [23]. The OHIP-14 is a 14 question questionnaire that measures people's perception of the social impact of oral disorders on their well-being [23].

Search criteria and strategies: Four electronic databases (MEDLINE via PubMed, EMBASE, the Cochrane Library and Web of Science) were searched on February $8^{\text {th }}, 2018$ using the search strategies detailed in Supplement Table 1. The search was re-run on February $10^{\text {th }}$, 2019 and one new systematic review was found [24] and one RCT studying a plant-based supplement (berberine) [9].

\section{Data collection and analysis}

Three independent reviewers (K.S.P., W.C.C.-M., J.M.P.) analyzed all titles and abstracts for inclusion that were found through hand-searched reference lists and electronic searches. The full text versions were re- trieved and analyzed if any titles or abstracts had inadequate information to decide to reject or include in the studies. A fourth reviewer (R.E.) resolved any disagreements during discussions about inclusion or rejections of studies that had lack of consensus. Each abstract had reasons for exclusion clearly outlined. Inclusion and exclusion criteria, number of participants, demographics and other data on study participants' characteristics were gathered during the qualitative synthesis phase. A standardized table was used to extract this data along with the interventions and outcomes that were assessed in each study.

Assessment of risk of bias was undertaken independently by three reviewers (K.S.P., W.C.C.-M., J.M.P.) guided by the Cochrane risk-of-bias tool [25]. Arisk of bias table was completed for each included study.

\section{Meta-analyses}

Studies reporting similar outcomes comparing natural products' group to placebo group in RCTs of patients with RAS were included in meta-analyses. Random-effects model was chosen due to the heterogeneity of the interventions (i.e. different natural products). Difference in means and 95\% Confidence intervals (Cl) were reported for outcomes ulcer size in $\mathrm{mm}$ and level of erythema and exudation at different time points. Standardized difference in means (SDM) and $95 \% \mathrm{Cl}$ were reported for pain intensity due to the use of three different pain scales by the studies. Risk ratios (RR) with 95\% Cl were reported for the binary outcome significant improvement in ulcer size (yes/no) defined as an efficacy index of $>70 \%$. All analyses were performed using Comprehensive Meta-analysis software v2 (Bio stat, Englewood, NJ, USA).

\section{Levels of evidence and summary of the review findings}

Quality of evidence assessment and summary of the review findings were conducted with the software GRADE profiler(C) (Grader(C), following the Cochrane Collaboration and GRADE Working Group recommendations [25]. In this systematic review we downgraded the quality of the evidence due to unclear/high risk of bias or due to imprecision (only two studies reporting the outcomes with less than 400 participants in total included in the meta-analysis [26]). 
Table 2: Summary of eligible RCT studies.

\begin{tabular}{|c|c|c|c|c|c|}
\hline Reference & $\begin{array}{l}\text { Country, } \\
\text { Study Type, } \\
\text { Total sample } \\
\text { size }\end{array}$ & $\begin{array}{l}\text { Interventions, } \\
\text { sample size per } \\
\text { group }\end{array}$ & $\begin{array}{l}\text { Control } \\
\text { intervention, } \\
\text { sample size }\end{array}$ & Inclusion criteria & $\begin{array}{l}\text { Gender and age } \\
\text { (average } \pm S D \text {, } \\
\text { range in years) }\end{array}$ \\
\hline $\begin{array}{l}\text { Amanlou, et } \\
\text { al. [11] }\end{array}$ & $\begin{array}{l}\text { Iran, RCT, } \\
\text { double } \\
\text { blinded, } \\
\mathrm{N}=60\end{array}$ & $\begin{array}{l}\text { S. khuzistanica } \\
\text { extract } 3 x \text { day, } n \\
=20 \\
\text { S. khuzistanica } \\
\text { essential oil, } \\
n=20\end{array}$ & $\begin{array}{l}\text { Hydroalcoholic } \\
\text { vehicle } \\
\text { (placebo) } \\
n=20\end{array}$ & $\begin{array}{l}\text { (1) History of RAS } \\
\text { (2) Currently suffering from } \\
\text { ulceration located on the oral } \\
\text { mucosa }\end{array}$ & $\begin{array}{l}28 \mathrm{M} / 32 \mathrm{~F} \\
28.48 \\
10-64 \text { years }\end{array}$ \\
\hline $\begin{array}{l}\text { Atanasovska } \\
\text { Stojanovska, } \\
\text { et al. [13] }\end{array}$ & $\begin{array}{l}\text { Macedonia, } \\
\text { RCT, double } \\
\text { blinded } \\
\mathrm{N}=20\end{array}$ & $\begin{array}{l}\text { Proaftol spray, } n \\
=10\end{array}$ & $\begin{array}{l}\text { Control spray, } \\
n=10\end{array}$ & $\begin{array}{l}\text { (1) RAS with a frequency of at least } \\
\text { 3-4 times a year. }\end{array}$ & $\begin{array}{l}\text { No gender specified } \\
20-30 \text { years }\end{array}$ \\
\hline $\begin{array}{l}\text { Babaee, et al. } \\
{[14]}\end{array}$ & $\begin{array}{l}\text { Iran, } \\
\text { randomized, } \\
\text { double-blind, } \\
\text { controlled } \\
\text { before-after } \\
\text { clinical trial } \\
\mathrm{N}=40\end{array}$ & $\begin{array}{l}\text { Myrtle oral paste, } \\
n=40\end{array}$ & $\begin{array}{l}\text { Placebo oral } \\
\text { paste, } \\
n=40\end{array}$ & $\begin{array}{l}\text { (1) } 18 \text { years of age or older, } \\
\text { (2) Clear history of RAS occurring at } \\
\text { least twice a year, } \\
\text { (3) Presenting with } 1-3 \text { aphthous } \\
\text { ulcers (< } 48 \text { h duration), measuring } \\
\text { no more than } 10 \mathrm{~mm} \text { in diameter, } \\
\text { (4) Had an expectation that their } \\
\text { ulcers normally takes }>5 \text { days to } \\
\text { resolve without treatment, } \\
\text { (5) No underlying medical or } \\
\text { hematological cause for their } \\
\text { ulceration. }\end{array}$ & $\begin{array}{l}17 \mathrm{M} / 23 \mathrm{~F} \\
29.5 \pm 10.3 \\
18-58 \text { years }\end{array}$ \\
\hline $\begin{array}{l}\text { Babaee, et al. } \\
{[15]}\end{array}$ & $\begin{array}{l}\text { Iran, RCT, } \\
\text { double } \\
\text { blinded } \\
\mathrm{N}=40\end{array}$ & $\begin{array}{l}\text { Aloe vera gel, } n \\
=20\end{array}$ & $\begin{array}{l}\text { Placebo gel, } \\
n=20\end{array}$ & $\begin{array}{l}\text { (1) Aged between } 15 \text { and } 35 \text { years } \\
\text { (2) Minor recurrent aphthous } \\
\text { singular lesions on their buccal } \\
\text { mucosa and mucosal zone of the } \\
\text { lips (after a medical diagnosis of } \\
\text { RAS minor) } \\
\text { (3) Without any other medical } \\
\text { complications } \\
\text { (4) Patients had noticed oral lesions } \\
\text { during the last two days }\end{array}$ & $\begin{array}{l}22 \mathrm{M} / 18 \mathrm{~F} \\
\text { Intervention group: } \\
27.95 \pm 7.96 \text { years } \\
\text { Placebo: } 29.25 \pm \\
7.48 \text { years }\end{array}$ \\
\hline $\begin{array}{l}\text { El-Haddad, et } \\
\text { al. [16] }\end{array}$ & $\begin{array}{l}\text { Kingdom } \\
\text { Saudi Arabia, } \\
\text { RCT, single- } \\
\text { blinded } \\
N=94\end{array}$ & $\begin{array}{l}\text { Honey-treated } \\
\text { group, } \\
n=34 \\
0.1 \% \\
\text { triamcinolone } \\
\text { acetonide, } \\
n=30\end{array}$ & $\begin{array}{l}\text { Orabase } \\
\text { control group, } \\
n=30\end{array}$ & $\begin{array}{l}\text { (1) Males and females aged from } \\
\text { 18-60 years old. } \\
\text { (2) Positive history of recurrent } \\
\text { aphthous ulceration that normally } \\
\text { last more than } 5 \text { days each episode } \\
\text { without treatment. } \\
\text { (3) Presence of } 1-5 \text { aphthous ulcers } \\
\text { that present for less than } 48 \text { hours } \\
\text { without treatment. } \\
\text { (4) Ulcer size not greater than } 5 \mathrm{~mm} \\
\text { in diameter. } \\
\text { (5) The ulcers are available for } \\
\text { topical application of the treated } \\
\text { agent. }\end{array}$ & $\begin{array}{l}28 \mathrm{M} / 66 \mathrm{~F} \\
18-60 \text { years }\end{array}$ \\
\hline
\end{tabular}




\begin{tabular}{|c|c|c|c|c|c|}
\hline $\begin{array}{l}\text { Hoseinpour, } \\
\text { et al. [17] }\end{array}$ & $\begin{array}{l}\text { Iran, } \mathrm{RCT}, \\
\text { double- } \\
\text { blinded } \\
\mathrm{N}=50\end{array}$ & $\begin{array}{l}\text { Mouth wash with } \\
\text { Rosa damascene } \\
1 \text { minute, } \\
\mathrm{N}=25\end{array}$ & $\begin{array}{l}\text { Placebo, } \\
n=25\end{array}$ & $\begin{array}{l}\text { (1) At least one aphthous ulcer } \\
\text { measuring no more than } 10 \mathrm{~mm} \text { in } \\
\text { diameter; } \\
\text { (2) Duration of the ulcer(s) } \leq 48 \\
\text { hours; } \\
\text { (3) Only patients with minor or } \\
\text { herpetic form ulcerations were } \\
\text { included. }\end{array}$ & $\begin{array}{l}27 \mathrm{M} / 23 \mathrm{~F} \\
\text { Rosa: } 34.4 \pm 9.6 \\
\text { years; } \\
\text { Placebo: } 33.6 \pm \\
14.4 \\
21-59 \text { years }\end{array}$ \\
\hline $\begin{array}{l}\text { Jiang, et al. } \\
{[10]}\end{array}$ & $\begin{array}{l}\text { China } \\
\text { RCT, double- } \\
\text { blinded } \\
\mathrm{N}=84\end{array}$ & $\begin{array}{l}\text { Berberine gelatin } \\
(10 \mathrm{~g}) \text { containing } \\
50 \mathrm{mg} \text { berberine, } \\
\mathrm{n}=42\end{array}$ & $\begin{array}{l}\text { Placebo agent, } \\
\mathrm{n}=42\end{array}$ & $\begin{array}{l}\text { (1) Both genders aged } 18 \text { to } 50 \\
\text { years; } \\
\text { (2) A history of RAS for a minimum } \\
\text { of } 6 \text { months with an average of } 1 \text { to } \\
2 \text { outbreaks per month and } 1 \text { to } 5 \\
\text { minor aphthae per outbreak; } \\
\text { (3) No analgesics use or other drugs } \\
\text { curing oral ulcer during the study; } \\
\text { (4) } 1 \text { to } 3 \text { aphthous ulcerations with } \\
\text { a size_5 and } 10 \text { mm in diameter; } \\
\text { for more than } 1 \text { ulceration, a } \\
\text { distance between ulcerations of } \\
\text { more than } 1 \text { cm; } \\
\text { (5) Time of ulceration onset within } \\
48 \text { hours; } \\
\text { (6) Ulcers in locations that are } \\
\text { easily accessible for evaluation and } \\
\text { treatment. }\end{array}$ & $\begin{array}{l}\text { Gender } \\
\text { Berberine: } 14 \\
\text { M/28F } \\
\text { Placebo: } 10 \mathrm{M} / 32 \mathrm{~F} \\
\text { Berberine: } 30.86 \pm \\
7.53 \\
19-51 \text { years } \\
\text { Placebo: } 31.19 \pm \\
6.00 \\
20-45 \text { years }\end{array}$ \\
\hline Liu, et al. [18] & $\begin{array}{l}\text { China, RCT, } \\
\text { double } \\
\text { blinded, } \\
\mathrm{N}=240 \\
\text { randomized, } \\
\mathrm{N}=227 \\
\text { completed } \\
\text { the study }\end{array}$ & $\begin{array}{l}\text { Toothpaste } 0.65 \% \\
\text { Yunnan Baiyao, } \\
n=113\end{array}$ & $\begin{array}{l}\text { Placebo } \\
\text { toothpaste, } \\
n=114\end{array}$ & $\begin{array}{l}\text { (1) Both male and female aged } 18 \\
\text { to } 65 \text {-years-old; } \\
\text { (2) Patients diagnosed as minor } \\
\text { recurrent aphthous stomatitis with } \\
\text { the duration of each ulcer in excess } \\
\text { of } 5 \text { days; } \\
\text { (3) Fresh ulcers available with less } \\
\text { than } 72 \text { hours eruption. }\end{array}$ & $\begin{array}{l}\text { 53M/174F } \\
\text { Yunnan: } 31.9 \pm \\
\text { 10.9 Placebo: } 31.4 \\
\pm 11.8\end{array}$ \\
\hline $\begin{array}{l}\text { Mansour, et } \\
\text { al. [19] }\end{array}$ & $\begin{array}{l}\text { Saudi Arabia, } \\
\text { RCT, double } \\
\text { blinded } \\
\mathrm{N}=90\end{array}$ & $\begin{array}{l}\text { Mucoadhesive gel } \\
\text { with aloe vera, } \\
\mathrm{n}=30 \\
\text { Mucoadhesive } \\
\text { gel with myrrh } \\
\text { extract, } \\
\mathrm{n}=30\end{array}$ & $\begin{array}{l}\text { Mucoadhesive } \\
\text { gel (placebo), } \\
n=30\end{array}$ & $\begin{array}{l}\text { (1) Presenting with } 1-3 \text { minor fresh } \\
\text { RAS lesions, with duration }<48 \mathrm{~h} \text {, } \\
\text { and not greater in diameter than } 5 \\
\mathrm{~mm} \text {. } \\
\text { (2) If any participant had more than } \\
\text { one ulcer, the one selected for } \\
\text { evaluation was the most recent one. }\end{array}$ & $\begin{array}{l}38 \mathrm{M} / 52 \mathrm{~F} \\
31.7 \pm 8.4 \\
18-36 \text { years }\end{array}$ \\
\hline $\begin{array}{l}\text { Pourahmad, } \\
\text { et al. [20] }\end{array}$ & $\begin{array}{l}\text { Iran, } \\
\text { RCT, double } \\
\text { blinded } \\
\mathrm{N}=93\end{array}$ & $\begin{array}{l}\text { Camel thorn } \\
\text { distillate, } \\
n=49\end{array}$ & $\begin{array}{l}\text { Distilled water, } \\
n=44\end{array}$ & $\begin{array}{l}\text { (1) An aphthous lesion on their oral } \\
\text { mucosa; } \\
\text { (2) History of recurrent similar } \\
\text { lesions. }\end{array}$ & $\begin{array}{l}\text { 49M/44F } \\
\text { Camel Thorn: } 27.4 \\
\text { years } \\
\text { Placebo: } 31.8 \text { years }\end{array}$ \\
\hline
\end{tabular}




\begin{tabular}{|c|c|c|c|c|c|}
\hline $\begin{array}{l}\text { Yang, et al. } \\
{[12]}\end{array}$ & $\begin{array}{l}\text { China, } \\
\text { RCT, } \\
\text { double- } \\
\text { Blinded } \\
\mathrm{N}=80\end{array}$ & $\begin{array}{l}\text { Pudilan } \\
\text { toothpaste, } \\
n=40\end{array}$ & $\begin{array}{l}\text { Placebo paste, } \\
n=40\end{array}$ & $\begin{array}{l}\text { (1) } 18 \text { to } 62 \text {-years-old; (2) have } \\
\text { been confirmed as having minor } \\
\text { aphthous ulcers (MiAUs) with } 1-3 \\
\text { ulcerous lesions and a maximum } \\
\text { lesion diameter < } 10 \text { mm; } \\
\text { (2) Have had MiAUs diagnosed at } \\
\text { least } 6 \text { months prior to this study } \\
\text { and not have required medication } \\
\text { for more than } 5 \text { days to recover } \\
\text { from any episode; } \\
\text { (3) Have had recent ulcerous } \\
\text { lesions occurring within } 48 \mathrm{~h} \text { prior } \\
\text { to the study and not received any } \\
\text { treatment. }\end{array}$ & $\begin{array}{l}\text { Unknown gender } \\
\text { and age }\end{array}$ \\
\hline
\end{tabular}

MiAUs: Minor Aphthous Ulcers.

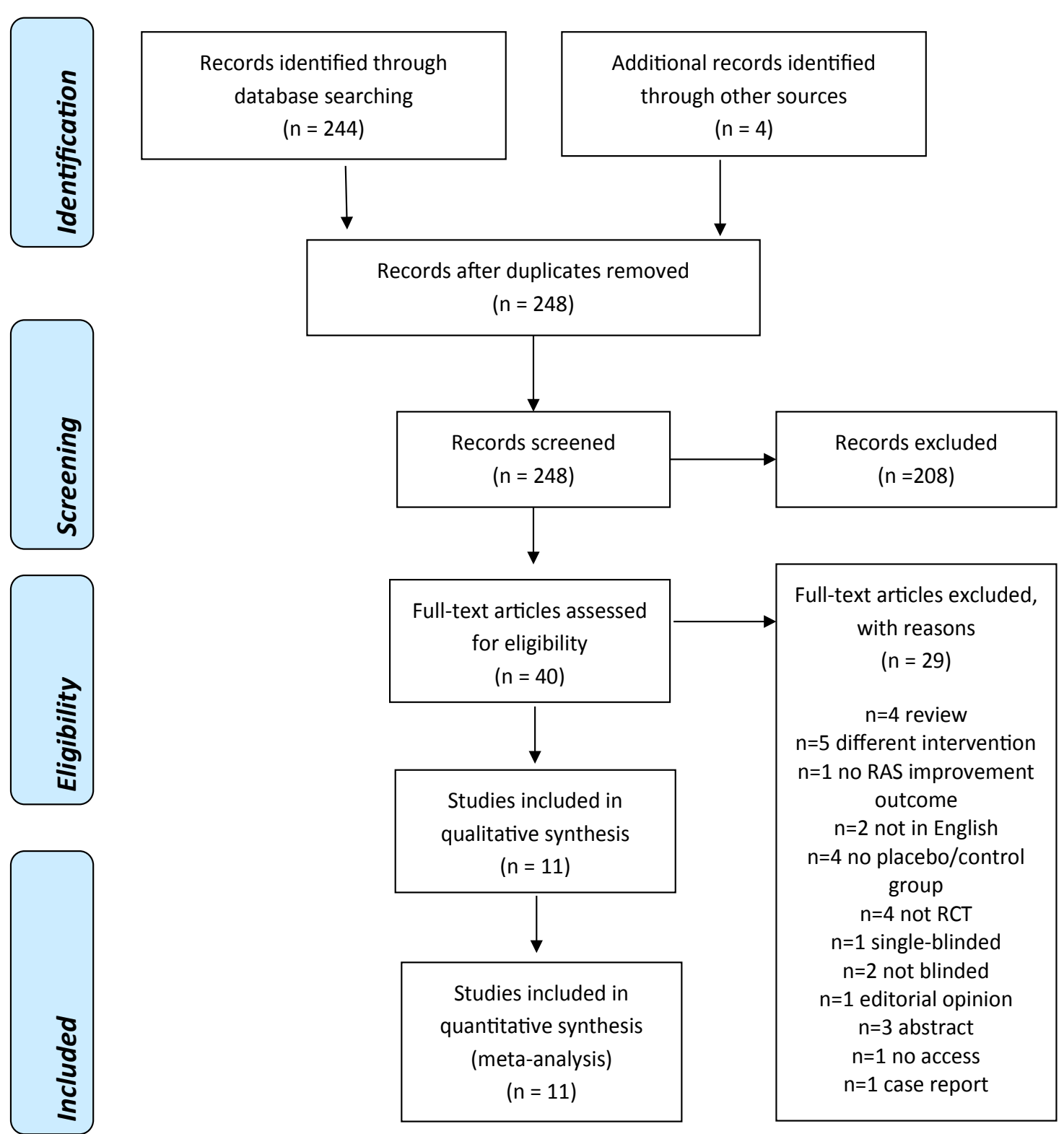

Figure 1: PRISMA flow diagram [8].

\section{Results}

\section{Results of the search}

The initial search strategy yielded 244 unduplicated references plus four references resultant from cross-refer- encing the bibliography sections of included studies and reviews. 248 references were assessed independently by three review authors, and based on the abstracts and titles these were reduced to 40 relevant manuscripts. All the 40 manuscripts identified were searched for full- 
text and analyzed for inclusion independently by three review authors. 11 manuscripts were relevant for inclusion. Table 2 shows a list of our included studies. Main reasons for exclusion for 29 references are reported in PRISMA flowchart (Figure 1).

\section{Included studies}

Ten double-blinded RCTS [9-13,15-19], and one single blinded study [14] were eligible for qualitative analysis to answer the question of efficacy of nutraceuticals on the treatment of Recurrent aphthous ulcers (RAS) (Table 2).

Population: A total of 694 patients were included in this review. All studies enrolled patients at only one center, and enrolled both male and female with more females overall [9-19]. The number of patients enrolled in each study ranged from 20 [11] to 217 [16]. The ages of the patients ranged from 10 [10] to 64 [10]. The inclusion criteria among the studies as well as the average age and gender distribution are presented in Table 2. Patients from the studies had a diagnosis of recurrent aphthous ulcers with present clinical signs and symptoms of ulcerations on the oral mucosa and history of RAS. Inclusion criteria in some studies specified lesions' minimum size, duration of lesion, time of onset and other characteristics as listed in Table 2.

Interventions: A total of eleven interventions were evaluated in this systematic review: Satureja khuzistanica [10], proaftol [11], myrtle [12], aloe vera [13,17], honey [14], rosa domascena [15], Yunnan baiyao [16], myrrh [17], camel thorn [18], berberine [9] and pudilankeyanning [19]. The carriers utilized included a paste, mixture, gel or spray applied directly to the lesion [10], a mouth rinse [13], and toothpaste [13].

Comparison groups: Patients in the comparison groups were labeled as controls and were provided placebos that contained inert ingredients. In two studies efforts were made to ensure that the placebo resembled the intervention in color and consistency $[9,15,19]$. The remaining eight studies did not designate if that was also done [10-14,16-18].

Outcomes: The primary outcome reported by the included studies was ulcer size in $\mathrm{mm}$, measured using a sterile calibrated dental probe with millimeter marking $[9,12,14-18]$ or a metal caliper [13]. Another primary outcome was pain intensity measured with various scales: Visual analog scale (VAS) on a $100 \mathrm{~mm}$ line labeled at one end "no soreness" and the other end "worst possible soreness" $[9,12]$ or a $10 \mathrm{~mm}$ scale $[13,17,19]$; pain intensity on a 0-3 scale with 0-no pain, 1-discomfort, 2-moderate pain and 3-severe pain [11-15]. Secondary outcomes included level of erythema and exudation were reported in three studies $[9,12]$. One study reported only average degree of erythema without any other information (i.e. standard deviation, percentiles) and could not be included in the meta-analysis [14]. One study [19] reported the degree of hyperemia on a scale 0-3 and could not be included in the meta-analysis as it is a different outcome than erythema and exudation combined. Another secondary outcome measured was the Efficacy index (EI) for ulcer size or pain, as defined by Meng, et al. [22] and Liu, et al. [16]. The El was evaluated for ulcers' size in two studies $[15,16]$ and for pain in one study [16]. Three outcomes were only evaluated

\section{Graph of Risk of Bias}

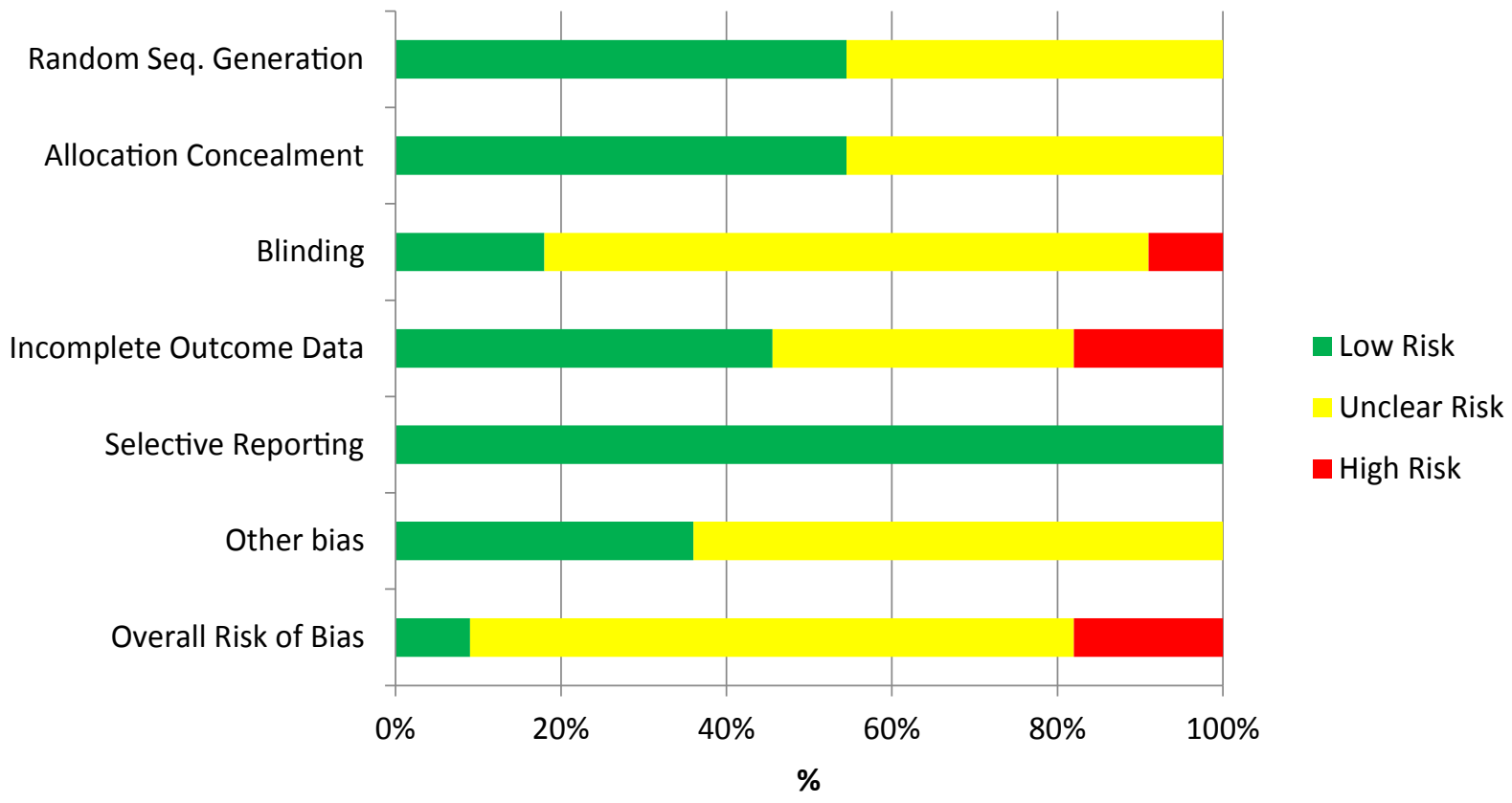

Figure 2: Summary of risk of bias of eligible randomized controlled trials. 
in one study, time to complete healing $[10,18]$, dates of pain elimination [10], and Oral health impact profile (OHIP) [12] and no meta-analysis could be undertaken.

\section{Risk of bias in included studies}

A summary of risk of bias table (Supplement Table 2) as well as a risk of bias graph (Figure 2) are presented in this review.

Random sequence generation: Method was identified as low risk of bias in six studies total $[9,14-17,19]$ because they used a computer based random number generator. Five studies $[10-13,18]$ were unclear risk for random sequence generation because they didn't specify the method they used. No studies were high risk.

Allocation concealment was considered low bias for six studies $[9,12,14-16,18]$ because the treatment assignments were hidden from both patients and investigators or a third party recorded the randomized codes and were not involved in the study. Five studies $[10,11,13,17,19]$ were considered unclear risk for allocation concealment because the studies allocation concealment methods were not described.

Blinding Two studies $[12,15]$ were considered to be low risk for blinding because the authors clearly stated that after selection, patients randomly assigned a number and were allocated to the placebo or experimental group were blinded as were the investigators delivering treatment, as were the outcome assessors and the analysts. The randomly assigned number was recorded in the protocol, and information regarding the contents

A

Ulcer size at days $3-4(\mathrm{~mm})$

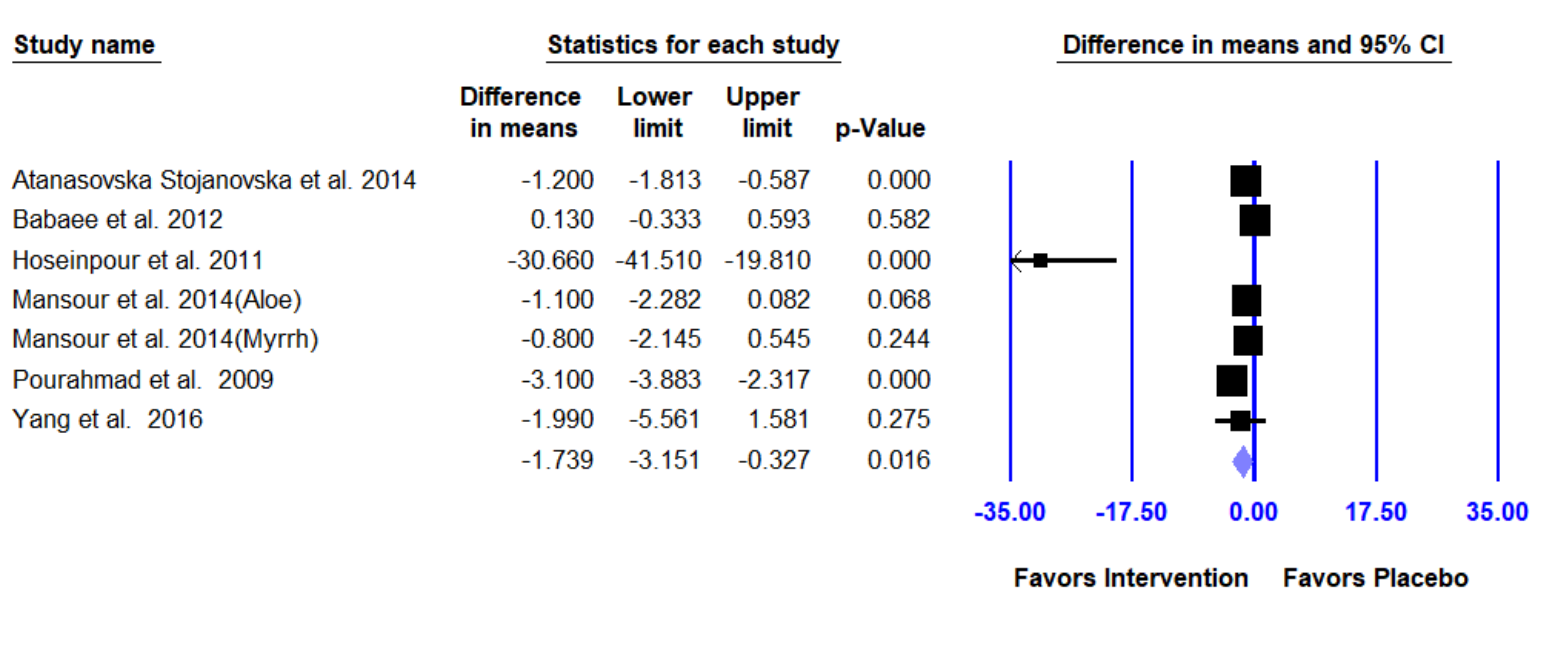

Random-effects model

Ulcer size at days 5-7 (mm)

\begin{tabular}{lrrrr} 
Study name & \multicolumn{4}{c}{ Statistics for each study } \\
\cline { 1 - 4 } & $\begin{array}{r}\text { Difference } \\
\text { in means }\end{array}$ & $\begin{array}{c}\text { Lower } \\
\text { limit }\end{array}$ & $\begin{array}{c}\text { Upper } \\
\text { limit }\end{array}$ & p-Value \\
Atanasovska Stojanovska et al. 2014 & -1.100 & -1.626 & -0.574 & 0.000 \\
Babaee et al. 2012 & 0.690 & 0.272 & 1.108 & 0.001 \\
Hoseinpour et al. 2011 & -14.000 & -20.970 & -7.030 & 0.000 \\
Mansour et al. 2014 (Aloe) & -1.700 & -2.882 & -0.518 & 0.005 \\
Mansour et al. 2014 (Myrrh) & -0.900 & -2.245 & 0.445 & 0.190 \\
Pourahmad et al. 2009 & -3.070 & -3.626 & -2.514 & 0.000 \\
Yang et al. 2016 & -2.930 & -6.001 & 0.141 & 0.061 \\
& -1.873 & -3.393 & -0.352 & 0.016
\end{tabular}

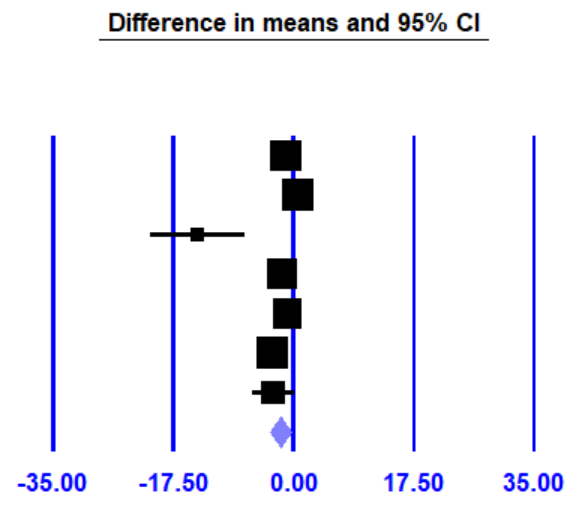

Favors Intervention Favors Placebo

Random-effects model

Figure 3: Meta-analyses for ulcer size in mm. A,B) Ulcer size was significantly decreased at days 3-4 and days 5-7 in the intervention groups compared to the placebo group. 
A

Study name
Atanasovska Stojanovska et al. 2014
Babaee et al. 2012
Hoseinpour et al. 2011
Mansour et al. 2014 (Aloe)
Mansour et al. 2014 (Myrrh)
Pourahmad et al. 2009
Yang et al. 2016

\section{Pain intensity at days 3-4}

\begin{tabular}{|c|c|c|c|}
\hline \multicolumn{4}{|c|}{ Statistics for each study } \\
\hline $\begin{array}{l}\text { d diff } \\
\text { means }\end{array}$ & $\begin{array}{l}\text { Lower } \\
\text { limit }\end{array}$ & $\begin{array}{l}\text { Upper } \\
\text { limit }\end{array}$ & p-Value \\
\hline-2.109 & -3.203 & -1.016 & 0.000 \\
\hline-0.298 & -0.922 & 0.325 & 0.348 \\
\hline-1.427 & -2.048 & -0.806 & 0.000 \\
\hline-0.227 & -0.848 & 0.395 & 0.474 \\
\hline-0.361 & -0.985 & 0.264 & 0.257 \\
\hline-1.674 & -2.147 & -1.201 & 0.000 \\
\hline 0.235 & -0.205 & 0.675 & 0.295 \\
\hline-0.794 & -1.447 & -0.141 & 0.017 \\
\hline
\end{tabular}

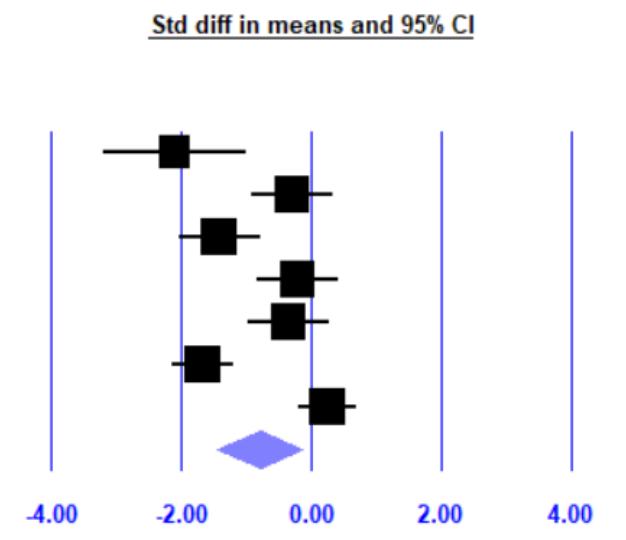

Favors Intervention Favors Placebo

Random-effects model

B

Pain intensity at days 5-7

\begin{tabular}{lrrrr} 
Study name & \multicolumn{5}{c}{ Statistics for each study } \\
\cline { 2 - 5 } & $\begin{array}{r}\text { Difference } \\
\text { in means }\end{array}$ & $\begin{array}{c}\text { Lower } \\
\text { limit }\end{array}$ & $\begin{array}{c}\text { Upper } \\
\text { limit }\end{array}$ & p-Value \\
Atanasovska Stojanovska et al. 2014 & -0.500 & -0.827 & -0.173 & 0.003 \\
Babaee et al. 2012 & -0.286 & -0.287 & -0.285 & 0.000 \\
Hoseinpour et al. 2011 & -1.670 & -2.319 & -1.021 & 0.000 \\
Mansour et al. 2014 (Aloe) & -0.600 & -2.240 & 1.040 & 0.473 \\
Mansour et al. 2014 (Myrrh) & -0.980 & -2.698 & 0.738 & 0.264 \\
Pourahmad et al. 2009 & -3.000 & -3.756 & -2.244 & 0.000 \\
Yang et al. 2016 & -0.700 & -1.351 & -0.049 & 0.035 \\
& -1.094 & -1.709 & -0.479 & 0.000
\end{tabular}

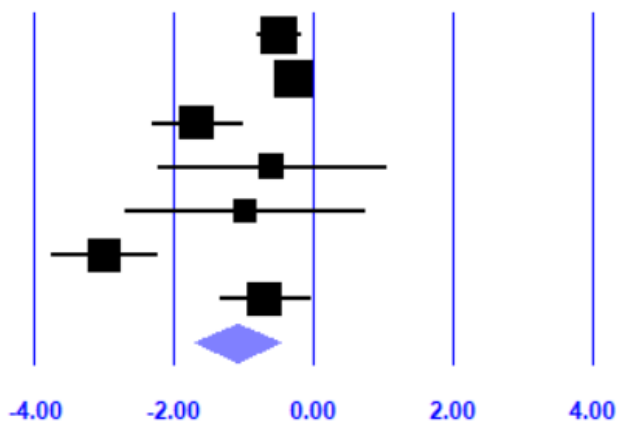

Favors Intervention Favors Placebo

Random-effects model

Figure 4: Meta-analysis for pain intensity. A,B) Pain intensity significantly decreased at days 3-4 and days 5-7 with a 'large' effect size in the intervention group compared to the placebo group. Due to different pain scales reported by the authors, the effect size reported for pain intensity is the 'Standardized Difference in Means' (SDM). Cohen suggested that SDM > 0.8 be considered a 'large' effect size.

became available after the completion of the study and statistical analysis. One study was considered to be high risk for blinding because they did not state that that they used randomized controlled trials in their blinding methods [14]. Eight studies [9-11,13,16-19] had unclear risk of bias for blinding as they did not go into detail about how the blinding was done, but stated that double blinding did occur.

Incomplete outcome data: Five studies $[13,15-17,19]$ included had no missing outcome data and were assessed as being at low risk of bias for this domain. Two studies $[11,14]$ had high risk for incomplete outcome data because all data does not seem to be completely addressed, intent to treat analysis is not stated, or number of drop outs or reasons for drop outs are not stated. Four studies $[9,10,12,18]$ were considered to have an unclear risk of bias for incomplete outcome data, intent to treat analysis not clearly stated or because the number of dropouts were stated, but the reason was not clear.

Selective reporting: All of the pre-specified outcomes were reported in the pre-specified way in all 
eleven included studies [9-19] therefore the selective reporting risk of bias was assessed as low for all of them.

Other potential sources of bias: In four studies $[10,15,17,18]$ there was a low risk of bias of other potential sources because they mentioned acceptable funding sources such as university based grants, no co-interventions were used and the groups were balanced at baseline. In seven studies [9,11-14,16,19] there was an unclear risk of bias of other potential sources because no funding sources were mentioned or there were no statements on co-interventions mentioned or not, and no statements on whether there were balanced groups at baseline or not.

Overall risk of bias: In conclusion, one study [15] was considered low risk. (Supplement Table 2; Figure $2)$, two studies $[11,14]$ were considered at high risk of bias and eight studies were considered unclear risk $[9,10,12,13,16-19]$.

\section{Meta-analyses results}

The primary outcome measures reported by the authors were the differences in post-treatment ulcer size $(\mathrm{mm})$ and pain intensity. Secondary outcomes included significant improvement in ulcer size at 3-4 days and 5-7 days and level of erythema and exudation (scale 0-3). All results reported used the random-effects model.

Ulcer size (mm): Six studies reported mean and standard deviation of ulcer size at 3-4 days $[11,13,15,17-$ 19].Natural products provided a statistically significantly better reduction in ulcer size $(\mathrm{mm})$ compared to placebo (Difference in means $=-1.739 ; 95 \% \mathrm{Cl}=$ -3.151 to $-0.327 ; p=0.016$ ) (Figure $3 a$ ). Similar results were found at 5-7 days (Figure $3 b$ ).

Pain intensity: Six studies reported mean and standard deviation of pain intensity at 3-4 days [11$14,16,19]$. Due to different pain scales reported by

\section{A Significant improvement in ulcer size at 3-4 days}

\begin{tabular}{|c|c|c|c|c|c|c|c|c|c|}
\hline \multirow[t]{2}{*}{ Study name } & \multicolumn{5}{|c|}{ Statistics for each study } & & \multicolumn{2}{|c|}{ Risk ratio and $95 \% \mathrm{Cl}$} & \\
\hline & $\begin{array}{l}\text { Risk } \\
\text { ratio }\end{array}$ & $\begin{array}{c}\text { Lower } \\
\text { limit }\end{array}$ & $\begin{array}{l}\text { Upper } \\
\text { limit }\end{array}$ & Z-Value & p-Value & & & & \\
\hline Hoseinpour et al. 2011 & 4.200 & 1.883 & 9.370 & 3.505 & 0.000 & & & & \\
\hline \multirow[t]{4}{*}{ Liu et al. 2012} & 1.737 & 1.034 & 2.920 & 2.085 & 0.037 & & & & \\
\hline & 2.556 & 1.084 & 6.030 & 2.144 & 0.032 & & & & \\
\hline & & & & & & 0.01 & 0.1 & 10 & 100 \\
\hline & & & & & & \multicolumn{2}{|c|}{ Favors Placebo } & Favors Interv & ion \\
\hline
\end{tabular}

Random-effects model

\section{B Significant improvement in ulcer size at 5-7 days}

\begin{tabular}{lccccrr} 
Study name & \multicolumn{5}{c}{ Statistics for each study } \\
\cline { 3 - 6 } & $\begin{array}{l}\text { Risk } \\
\text { ratio }\end{array}$ & $\begin{array}{c}\text { Lower } \\
\text { limit }\end{array}$ & $\begin{array}{c}\text { Upper } \\
\text { limit }\end{array}$ & Z-Value & p-Value \\
Hoseinpour et al. 2011 & 1.889 & 1.300 & 2.745 & 3.335 & 0.001 \\
Liu et al. 2012 & 1.327 & 1.059 & 1.663 & 2.460 & 0.014 \\
& 1.532 & 1.091 & 2.152 & 2.463 & 0.014
\end{tabular}

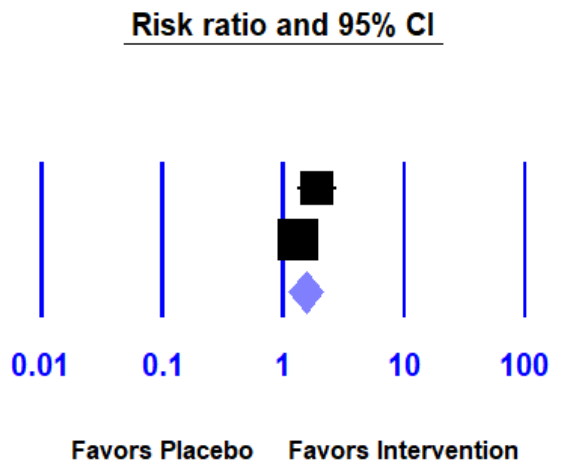

Random-effects model

Figure 5: Meta-analysis for significant improvement in ulcer size. A) Patients using natural products were 2.556 times as likely to significantly improve compared to placebo at days 3-4 and B) 1.532 times as likely to improve at days 5-7. 
the authors, the effect size reported for pain intensity was the 'Standardized difference in means' (SDM). Cohen suggested that an absolute value of SDM between 0.2 and 0.8 be considered a 'moderate' effect size, and a SDM $>0.8$ to be a 'large' effect. Natural products showed significantly better reduction in pain intensity compared to placebo at 3-4 days (SDM $=-0.794 ; 95 \% \mathrm{Cl}=-1.447$ to $-0.141 ; \mathrm{p}=0.017$ ) (Figure 4a) and at day 6 (SDM $=-1.094 ; 95 \% \mathrm{Cl}=-1.709$ to -0.479; $p<0.001$ ) (Figure $4 b$ ).

Significant improvement in ulcer size: Two studies $[15,19]$ reported significant improvement in ulcer size. They paired $\mathrm{EI}=100 \%$ and $\mathrm{EI}=70-100 \%$ categories as considered significant improvement of ulcer and $\mathrm{EI}=$ 0-30\% and $\mathrm{El}=30-70 \%$ as non-significant improvement $[15,19]$. The patients using natural products were 2.556 times as likely to improve than subjects using placebo at 3-4 days (Risk ratio $(\mathrm{RR})=2.556 ; 95 \% \mathrm{Cl}=1.084$ to $6.030 ; p=0.032$ ) (Figure 5a) and 1.532 times as likely to improve than subjects using placebo at 5-7 days (RR $=1.532 ; 95 \% \mathrm{Cl}=1.091$ to $2.152 ; \mathrm{p}=0.014$ ) (Figure $5 b$ ).
Level of erythema and exudation: Two studies $[9,12]$ reported level of erythema and exudation on a 0-3 scale. We found no significant improvement in level of erythema and exudation at day 2 nor day 6 (Supplement Figure 1).

Summary of the evidence and quality of the findings (GRADE): Quality of evidence was moderate due to unclear/high risk of bias for ulcer size and pain intensity at 3-4 days and 5-7 days. Quality of evidence was low due to unclear/high risk of bias and imprecision for outcomes 'significant improvement in ulcer size' and 'level of erythema and exudation' with only two studies reporting the outcomes with less than 400 participants in total included in the meta-analysis [26]. Moderate evidence grading indicates that further research is likely to have an important impact on our confidence in the estimate of effect and may change the estimate. Low evidence grading indicates that further research is very likely to have an important impact on our confidence in the estimate of effect and it is likely to change the estimate (Table 3).

Table 3: Summary of the evidence and quality of the findings (GRADE).

\begin{tabular}{|c|c|c|c|c|c|}
\hline \multicolumn{6}{|c|}{ Natural products versus placebo in the treatment of RAS } \\
\hline \multirow[t]{2}{*}{ Outcomes } & \multirow{2}{*}{$\begin{array}{l}\text { No of } \\
\text { participants } \\
\text { (studies) } \\
\text { Follow up }\end{array}$} & \multirow{2}{*}{$\begin{array}{l}\text { Quality of the } \\
\text { evidence } \\
\text { (GRADE) }\end{array}$} & \multirow{2}{*}{$\begin{array}{l}\text { Relative } \\
\text { effect } \\
(95 \% \mathrm{Cl})\end{array}$} & \multicolumn{2}{|c|}{ Anticipated absolute effects } \\
\hline & & & & $\begin{array}{l}\text { Risk with } \\
\text { placebo }\end{array}$ & $\begin{array}{l}\text { Risk difference with Natural products } \\
(95 \% \mathrm{Cl})\end{array}$ \\
\hline $\begin{array}{l}\text { Ulcer size } 3-4 \text { days } \\
(\mathrm{mm})\end{array}$ & $\begin{array}{l}373 \\
\text { (7 studies) } \\
3-4 \text { days }\end{array}$ & $\begin{array}{l}\oplus \oplus \oplus \ominus \\
\text { MODERATE } \\
\text { due to risk of } \\
\text { bias }\end{array}$ & NA & NA & $\begin{array}{l}\text { The mean ulcer size at } 3-4 \text { days in the } \\
\text { intervention groups was }-1.739 \mathrm{~mm} \\
\text { lower than the placebo groups } \\
(-3.151 \text { to }-0.327 \text { lower) }\end{array}$ \\
\hline $\begin{array}{l}\text { Ulcer size } 5-7 \text { days } \\
(\mathrm{mm})\end{array}$ & $\begin{array}{l}373 \\
\text { (7 studies) } \\
3-4 \text { days }\end{array}$ & $\begin{array}{l}\oplus \oplus \oplus \ominus \\
\text { MODERATE } \\
\text { due to risk of } \\
\text { bias }\end{array}$ & NA & NA & $\begin{array}{l}\text { The mean ulcer size at } 5-7 \text { days in the } \\
\text { intervention groups was }-1.873 \mathrm{~mm} \\
\text { lower than the placebo groups } \\
\text { (-3.393 to }-0.352 \text { lower) }\end{array}$ \\
\hline $\begin{array}{l}\text { Pain intensity at 3-4 } \\
\text { days } \\
\text { Various scales }\end{array}$ & $\begin{array}{l}373 \\
\text { ( } 7 \text { studies) } \\
3-4 \text { days }\end{array}$ & $\begin{array}{l}\oplus \oplus \oplus \ominus \\
\text { MODERATE } \\
\text { due to risk of } \\
\text { bias }\end{array}$ & NA & NA & $\begin{array}{l}\text { The mean pain intensity at } 3-4 \text { days } \\
\text { in the intervention groups was }-0.794 \\
\text { standard deviations lower } \\
(-1.447 \text { to }-0.141 \text { lower) }\end{array}$ \\
\hline $\begin{array}{l}\text { Pain intensity at 5-7 } \\
\text { days } \\
\text { Various scales }\end{array}$ & $\begin{array}{l}373 \\
\text { (7 studies) } \\
5-7 \text { days }\end{array}$ & $\begin{array}{l}\oplus \oplus \oplus \ominus \\
\text { MODERATE } \\
\text { due to risk of } \\
\text { bias }\end{array}$ & NA & NA & $\begin{array}{l}\text { The mean pain intensity at } 5-7 \text { days } \\
\text { in the intervention groups was }-1.094 \\
\text { standard deviations lower } \\
(-1.709 \text { to }-0.479 \text { lower) }\end{array}$ \\
\hline $\begin{array}{l}\text { Significant } \\
\text { improvement in ulcer } \\
\text { size at } 3-4 \text { days }\end{array}$ & $\begin{array}{l}277 \\
\text { ( } 2 \text { studies) } \\
3-4 \text { days }\end{array}$ & $\begin{array}{l}\oplus \oplus \ominus \ominus \\
\text { LOW }^{1,2} \\
\text { due to } \\
\text { imprecision and } \\
\text { risk of bias }\end{array}$ & $\begin{array}{l}\text { RR } 2.556 \\
(1.084 \text { to } \\
6.030)\end{array}$ & $\begin{array}{l}165 \text { per } \\
1000\end{array}$ & $\begin{array}{l}257 \text { more per } 1000 \\
\text { (from } 14 \text { more to } 832 \text { more) }\end{array}$ \\
\hline $\begin{array}{l}\text { Significant } \\
\text { improvement in ulcer } \\
\text { size at } 5-7 \text { days }\end{array}$ & $\begin{array}{l}277 \\
(2 \text { studies }) \\
6 \text { days }\end{array}$ & $\begin{array}{l}\oplus \oplus \ominus \ominus \\
\text { LOW }^{1,2} \\
\text { due to } \\
\text { imprecision and } \\
\text { risk of bias }\end{array}$ & $\begin{array}{l}\text { RR } 1.532 \\
(1.091 \text { to } \\
2.152)\end{array}$ & $\begin{array}{l}504 \text { per } \\
1000\end{array}$ & $\begin{array}{l}268 \text { more per } 1000 \\
\text { (from } 46 \text { more to } 580 \text { more) }\end{array}$ \\
\hline
\end{tabular}




\begin{tabular}{|c|c|c|c|c|c|}
\hline $\begin{array}{l}\text { Level of erythema and } \\
\text { exudation at day } 2 \\
\text { (scale } 0-3 \text { ) }\end{array}$ & $\begin{array}{l}162 \\
(2 \text { studies) } \\
2 \text { days }\end{array}$ & $\begin{array}{l}\bigoplus \oplus \ominus \ominus \\
\text { LOW }^{1,2} \\
\text { due to } \\
\text { imprecision and } \\
\text { risk of bias }\end{array}$ & NA & NA & $\begin{array}{l}\text { The mean level of erythema and } \\
\text { exudation in the intervention groups was } \\
-0.779 \text { lower (scale } 0-3) \text { at day } 2 \\
(-1.738 \text { lower to }+0.180 \text { higher) }\end{array}$ \\
\hline $\begin{array}{l}\text { Level of erythema and } \\
\text { exudation at day } 6 \\
\text { (scale } 0-3 \text { ) }\end{array}$ & $\begin{array}{l}162 \\
\text { ( } 2 \text { studies) } \\
6 \text { days }\end{array}$ & $\begin{array}{l}\oplus \oplus \ominus \ominus \\
\text { LOW }^{1,2} \\
\text { due to } \\
\text { imprecision and } \\
\text { risk of bias }\end{array}$ & NA & NA & $\begin{array}{l}\text { The mean level of erythema and } \\
\text { exudation in the intervention groups was } \\
-0.865 \text { lower (scale } 0-3) \text { at day } 6 \\
(-1.938 \text { lower to }+0.208 \text { higher) }\end{array}$ \\
\hline
\end{tabular}

GRADE Working Group grades of evidence.

High quality: Further research is very unlikely to change our confidence in the estimate of effect.

Moderate quality: Further research is likely to have an important impact on our confidence in the estimate of effect and may change the estimate.

Low quality: Further research is very likely to have an important impact on our confidence in the estimate of effect and is likely to change the estimate.

Very low quality: We are very uncertain about the estimate.

$190 \%$ of the studies had an overall unclear or high risk of bias

${ }^{2}$ Only two studies reported this outcome with small sample size $<400$ participants

$\mathrm{Cl}$ : Confidence Interval; RR: Risk Ratio; NA: Not Available.

\section{Discussion}

\section{Summary of main results}

Ten double-blinded RCTS [9-13,15-19], and one single blinded study [14] were eligible for qualitative analysis to answer the question of efficacy of natural products on the treatment of RAS. A total of eleven interventions (plant-based and honey) were under study in the included RCTs [9-19]. One study [15] was considered low risk, two studies $[11,14]$ were considered at high risk of bias and eight studies were considered unclear risk $[9,10,12,13,16-19]$ (Supplement Table 2 and Figure 2).

Natural products provided significantly better reduction in ulcer size $(\mathrm{mm})$ at 3-4 days $(\mathrm{p}=0.016)$ and 5-7 days $(p=0.016)$ compared to placebo. The group using natural products showed significant improvement in ulcer size compared to placebo at 3-4 days ( $p$ $=0.032$ ). At 5-7 days, people using natural products were 1.532 times as likely to improve than subjects using placebo $(p=0.014)$. Compared to dexamethasone, a clinical study reported that dexamethasone shows significant ulcer size reduction at day 6 ( $p<$ 0.001 ) compared to placebo, but no data was reported before day 6 [27]. These results seem to make natural products an alternative to the more commonly used corticosteroid. However, the clinical relevance of the ulcer size might not be as important to patients as it is pain reduction.

Drugs like triamcinolone ointment and dexamethasone, have been reported to be more effective than placebo in reducing pain $(p<0.01$ for triamcinolone, $p=0.001$ for dexamethasone) [27]. In our systematic review, natural products showed significantly better reduction in pain intensity (various pain scales reported) compared to placebo at 3-4 days $(p=0.017)$ with similar results at 5-7 days $(p<0.001)$. These results do not necessarily imply a clinical significance to the patient, and further studies are necessary to corroborate the results of this systematic review.

\section{Agreements and disagreements with other stud- ies or reviews}

The results of this systematic review agree with a systematic review published in 2018 by Heydarpour, et al. evaluating plant derived topical interventions for the treatment of RAS [28]. The primary difference between our review and Heydarpour, et al. [28] review is that ours included a meta-analysis of the interventions. Heydarpour, et al. [28] evaluated non-pharmaceutical interventions in the treatment of RAS and reached the following conclusion: Due to the complex etiology of RAS, the unpredictability of outcomes resolution with current treatment modalities and the potential for adverse effects associated with systemic medicaments, local treatments with fewer side effects are desired and greater numbers of studies evaluating these treatments are needed. Another review by Hamedi, et al. conducted in 2016 also evaluated plant based interventions for the treatment of RAS [29]. The focus of Hamedi, et al. [29] review was the mechanisms by which the plants may exert their benefits pharmacologically. The effects of the plants evaluated included antibacterial, anti-inflammatory, immune modulatory and anti-viral benefits.

In our systematic review, when evaluating primary outcome measures, the natural products under study yielded improvements in pain level and lesion size. The Heydarpour, et al. review yielded similar results. No significant side effects were revealed, only slight side 
effects such as mild burning sensation (S. khuzistanica) and slight-to-moderate irritation ( $A$. vulgaris), which spontaneously relieved. Combining the results of these two reviews indicates that there is both a subjective and objective benefit derived from utilization of plantbased, non-pharmaceutical interventions.

\section{Heterogeneity of the review}

Review authors tried to minimize heterogeneity by including only studies with patients with RAS receiving a natural product or placebo, excluding vitamins and products with herbs and vitamins (such as LongoVital). However, some heterogeneity was present; in particular, there were different interventions in all studies and no consistent use of standard in diagnosis of RAS. Furthermore, measurements were not taken at the same intervals for RAS ulcer size and pain intensity in all studies. In addition, parameters were not similar in all studies in what constitutes RAS and by whom it was diagnosed by. There was some heterogeneity in the fact that pain intensity was measured with various scales and also the days at which the lesions' size and pain were measured.

\section{Overall completeness and applicability of evi- dence}

Four electronic databases were searched, MEDLINE via PubMed, the Web of Science, the Cochrane Library and EMBASE up through January 2019. All included studies, reviews and systematic reviews were cross-referenced for relevant trials. Three reviewers (W.C.C., K.S.P., J.M.P.) individually assessed abstracts and titles to determine eligibility. Articles not available in English were excluded. The results of this systematic review are applicable to males and females, 10 to 64-years-old, diagnosed with RAS.

\section{Quality of the evidence}

Only randomized controlled trials (ten double-blinded RCTS [9-13,15-19], and one single blinded study [14]) were eligible for qualitative analysis to answer the question of efficacy of natural products on the treatment of RAS by choice of the authors, as high-quality RCTs can provide the best evidence in comparing the effects of natural products to placebo on pain and ulcer size in RAS. However, of the 11 RCTs included in the qualitative analysis, one study [15] was considered low risk, two studies [11,14] were considered at high risk of bias and eight studies were considered unclear risk $[9,10,12,13,16-19]$. The quality of the evidence was very low to moderate due to risk of bias, small total sample size of only 694 participants, small number of eligible studies in each meta-analysis due to heterogeneity of the outcomes reported and in some cases, wide variance of point estimates and statistical heterogeneity. In particular, there were different interventions in all studies and no consistent use of a standard in diagnosis of
RAS. Furthermore, measurements were not taken at the same intervals for RAS ulcer size and pain in all studies. In addition, parameters were not similar in all studies in what constitutes RAS and by whom it was diagnosed by.

\section{Implications for research}

Natural products may be effective in the treatment of RAS, but greater research focus needs to be placed on specific protocols, the nature of the intervention, patient access to the intervention and clinical relevance. Although the medicaments evaluated in this analysis yielded positive results, it was unclear whether these results would be applicable clinically. Meta-analyses indicated that those interventions that showed greater efficacy over placebo reduced lesion pain and lesion longevity by such a small degree and short timeframe, that investment in these medicaments may not be worthwhile from a clinical standpoint. Future studies may produce a specific regimen of non-pharmaceutical interventions that can be combined with pharmaceutical medicaments, may develop a protocol that leads to prevention of lesions, may result in a method of adjunctive use of non-pharmaceutical topical interventions, or may lead to the development of a new drug that is entirely plant-based that has both high efficacy and low risk of adverse events. Further research should also include possible drug-drug interactions.

\section{Conclusions}

The utilization of natural products for the treatment of ailments is not new. Despite still being a popular option, the data supporting their use is limited. In this systematic review, we analyzed the available data for a selected group of natural products, plant-based and honey. In general, these natural products provided a significantly better reduction in ulcer size and pain compared to placebo when used for the treatment of RAS. However, these results should be taken cautiously since most of the studies were assessed at unclear risk of bias and the studies were heterogeneous. These results do not necessarily imply a clinical significance to the patient, and further studies with good quality methodology are needed for each particular natural product.

\section{Acknowledgments}

The authors have no funding and no conflicts of interest.

\section{Sources of Support}

None.

\section{Conflicts of Interest}

None.

\section{Statement of Equal Authors' Contribution}

All authors contributed to the design and imple- 
mentation of the systematic review and writing of the manuscript. Dr. Enciso is responsible for the statistical analyses.

\section{Funding}

This research did not receive any specific grant from funding agencies in the public, commercial, or not-forprofit sectors.

\section{References}

1. Rodríguez-Archilla A, Raissouni T (2017) Randomized clinical trial of the effectiveness of complementary therapies for recurrent aphthous stomatitis. Med Clin 149: 55-60.

2. Rakel D (2015) Aphthous stomatitis. Katsambas Andreas, Lotti Torello, Dessinioti Clio, D'Erme AM (4 ${ }^{\text {th }}$ edn), Springer, Verlag Berlin Heidelberg.

3. Akintoye S, Greenberg MS (2014) Recurrent aphthous stomatitis. Dent Clin North Am 58: 281-297.

4. Cui Ricky Z, Bruce AJ, Rogers RS (2016) Recurrent aphthous stomatitis. Clin Dermatol 34: 475-481.

5. Lehman JS, Rogers RS (2016) Acute oral ulcers. Clin Dermatol 34: 470-474.

6. Schemel Suárez M, López López J, Chimenos Küstner E (2015) Oral ulcers: Differential diagnosis and treatment. Med Clín 145: 499-503.

7. Ji H, Li X, Zhang HY (2009) Can thousands of years of ancient medical knowledge lead us to new and powerful drug combinations in the fight against cancer and dementia? EMBO Rep 10: 194-200.

8. Moher D, Liberati A, Tetzlaff J, Altman DG, PRISMA Group (2009) Preferred reporting items for systematic reviews and meta-analyses: The PRISMA statement. PLoS Med 6.

9. Jiang XW, Zhang Y, Zhu YL, Zhang H, Lu K, et al. (2013) Effects of berberine gelatin on recurrent aphthous stomatitis: A randomized, placebo-controlled, double-blind trial in a Chinese cohort. Oral Surg Oral Med Oral Pathol Oral Radiol 115: 212-217.

10. Amanlou M, Babaee N, Saheb-Jamee M, Salehnia A, Farsam H, et al. (2007) Efficacy of Satureja khuzistanica extract and its essential oil preparations in the management of recurrent aphthous stomatitis. Daru 15: 231-235.

11. Atanasovska Stojanovska A, Popovska M, Muratovska I, Mitic K, Stefanovska E, et al. (2014) Therapeutic effect of proaftol in treatment of recurrent aphthous stomatitis. Pril 35: 195-202.

12. Babaee N, Mansourian A, Momen-Heravi F, Moghadamnia A, Momen-Beitollahi J (2014) The efficacy of a paste containing Myrtus communis (Myrtle) in the management of recurrent aphthous stomatitis: A randomized controlled trial. Clin Oral Investig 14: 65-70.

13. Babaee N, Zabihi E, Mohseni S, Moghadamnia AA (2012) Evaluation of the therapeutic effects of Aloe vera gel on minor recurrent aphthous stomatitis. Dent Res J 9: 381-385.

14. El-Haddad SA, Asiri FY, Al-Qahtani HH, Al-Ghmlas AS (2014) Efficacy of honey in comparison to topical corticosteroid for treatment of recurrent minor aphthous ulceration: $A$ randomized, blind, controlled, parallel, double-center clinical trial. Quintessence Int 45: 691-701.

15. Hoseinpour $\mathrm{H}$, Peel SA, Rakhshandeh $\mathrm{H}$, Forouzanfar A, Taheri M, et al. (2011) Evaluation of rosa damascena mouthwash in the treatment of recurrent aphthous stomati- tis: a randomized, double-blinded, placebo-controlled clinical trial. Quintessence Int 42: 483-491.

16. Liu X, Guan X, Chen R, Hua H, Liu Y, et al. (2012) Repurposing of yunnan baiyao as an alternative therapy for minor recurrent aphthous stomatitis. Evid Based Complement Altern Med.

17. Mansour G, Ouda S, Shaker A, Abdallah HM (2014) Clinical efficacy of new aloe vera- and myrrh-based oral mucoadhesive gels in the management of minor recurrent aphthous stomatitis: A randomized, double-blind, vehicle-controlled study. J Oral Pathol Med 43: 405-409.

18. Pourahmad M, Rahiminejad M, Fadaei S, Kashafi H (2010) Effects of camel thorn distillate on recurrent oral aphthous lesions. J Dtsch Dermatol Ges 8: 348-352.

19. Yang Y, Zhang T, Dong Z, Wu Y, Hong X, et al. (2016) Short-term efficacy of pudilan keyanning toothpaste in treatment of minor recurrent aphthous ulcers. Evid Based Complement Altern Med.

20. Greer RO, Lindenmuth JE, Juarez T, Khandwala A (1993) A double-blind study of topically applied $5 \%$ amlexanox in the treatment of aphthous ulcers. J Oral Maxillofac Surg 51: 243-248.

21. Liu J, Zeng X, Chen Q, Cai Y, Chen F, et al. (2006) An evaluation on the efficacy and safety of amlexanox oral adhesive tablets in the treatment of recurrent minor aphthous ulceration in a Chinese cohort: A randomized, double-blind, vehicle-controlled, unparallel multicenter clinical trial. Oral Surg Oral Med Oral Pathol Oral Radiol Endod 102: 475481.

22. Meng W, Dong Y, Liu J, Wang Z, Zhong X, et al. (2009) A clinical evaluation of amlexanox oral adhesive pellicles in the treatment of recurrent aphthous stomatitis and comparison with amlexanox oral tablets: A randomized, placebo controlled, blinded, multicenter clinical trial. Trials 10: 30 .

23. Slade GD (1997) Derivation and validation of a short-form oral health impact profile. Community Dent Oral Epidemiol 25: $284-290$.

24. Zhang Y, Ng KH, Kuo CY, Wu D (2018) Chinese herbal medicine for recurrent aphthous stomatitis: A protocol for systematic review and meta-analysis. Medicine 97.

25. Higgins J, Green S (2011) Cochrane handbook for systematic reviews of interventions version 5.1.0.

26. Schwingshackl L, Knüppel S, Schwedhelm C, Hoffmann G, Missbach B, et al. (2016) Perspective: Nutri grade: A scoring system to assess and judge the meta-evidence of randomized controlled trials and cohort studies in nutrition research. Adv Nutr 7: 994-1004.

27. Staines K, Greenwood M (2015) Aphthous ulcers (recurrent). BMJ Clin Evid.

28. Heydarpour F, Abasabadi M, Shahpiri Z, Vaziri S, Nazari $\mathrm{HA}$, et al. (2018) Medicinal plant and their bioactive phytochemicals in the treatment of recurrent aphthous ulcers: A review of clinical trials. Pharmacogn Rev 12: 27-39.

29. Hamedi S, Sadeghpour O, Shamsardekani MR, Amin G, Hajighasemali D, et al. (2016) The most common herbs to cure the most common oral disease: Stomatitis recurrent aphthous ulcer (RAU). Iran Red Crescent Med J 18.
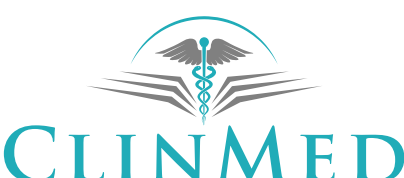

INTERNATIONAL LIBRARY 


\section{A) Level of erythema and exudation (scale 0-3) at day 2}

Study name

Statistics for each study

Difference in means and $95 \% \mathrm{Cl}$

Difference Lower Upper
in means limit limit $p$-Value

Babaee et al. 2010

$\begin{array}{rrrr}-1.160 & -2.509 & 0.189 & 0.092 \\ -0.390 & -1.753 & 0.973 & 0.575 \\ -0.779 & -1.738 & 0.180 & 0.111\end{array}$

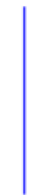

$-8.00$

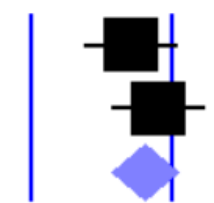

$-4.00$

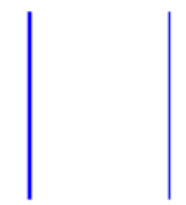

4.00

Favors Intervention Favors Placebo

Random-effects model

\section{B) Level of erythema and exudation (scale 0-3) at day 6}

Study name

$\begin{array}{lrrrrr} & \begin{array}{c}\text { Difference } \\ \text { in means }\end{array} & \begin{array}{c}\text { Lower } \\ \text { limit }\end{array} & \begin{array}{c}\text { Upper } \\ \text { limit }\end{array} & \text { p-Value } \\ \text { Babaee et al. 2010 } & -1.070 & -2.553 & 0.413 & 0.157 \\ \text { Jiang et al. 2013 } & -0.640 & -2.193 & 0.913 & 0.419 \\ & -0.865 & -1.938 & 0.208 & 0.114\end{array}$

\section{Difference in means and $95 \% \mathrm{Cl}$}
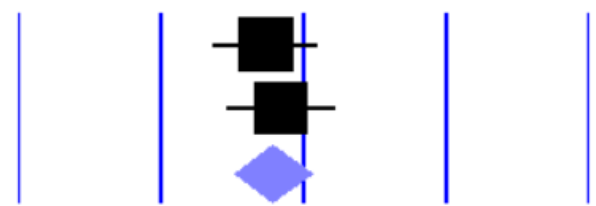

$-8.00$

$$
-4.00
$$

0.00

4.00

Random-effects model

Supplement Figure 1: Meta-analysis for level erythema and exudation at A) Day 2 and B) Day 6. 
Supplement Table 1: Electronic search strategies.

\begin{tabular}{|c|c|}
\hline Database & Search strategy \\
\hline $\begin{array}{l}\text { MEDLINE via PubMed } \\
\text { (searched on } 2 / 8 / 2018 \\
\text { and } 2 / 10 / 2019 \text { ) limited } \\
\text { to English language and } \\
\text { Humans }\end{array}$ & $\begin{array}{l}\text { (Herbal supplement" or dietary supplement" or nutraceutical" or vitamin* or multivitamin* or } \\
\text { perilla oil or longovital or camel thorn or zinc sulphate or beta-glucan or bee-propolis or "drugs, } \\
\text { chinese herbal" [Mesh] or "plant extracts" [Mesh] or "dietary supplements" [Mesh] or honey or } \\
\text { "complementary therapies" [Mesh] or aloe vera or myrrh or "sapogenins/therapeutic use"[MAJR] } \\
\text { or medicinal plants or "plants, medicinal" [Mesh]) and (recurrent aphthous stomatitis or recurrent } \\
\text { aphthous ulcer" or "stomatitis, aphthous" [Mesh]) }\end{array}$ \\
\hline $\begin{array}{l}\text { The Web of Science } \\
\text { (searched on } 2 / 8 / 2018 \\
\text { and } 2 / 10 / 2019 \text { ) }\end{array}$ & $\begin{array}{l}\text { Topic: (Herbal supplement or dietary supplement }{ }^{*} \text { or nutraceutical }{ }^{*} \text { or vitamin* or multivitamin }{ }^{*} \text { or } \\
\text { perilla oil or longovital or camel thorn or zinc sulphate or beta-glucan or bee-propolis or plant extract } \\
\text { or chinese herbal or honey or complementary therapies or aloe vera or myrrh or medicinal plant*) } \\
\text { and topic: (recurrent aphthous stomatitis or recurrent aphthous ulcer }{ }^{*} \text { ) }\end{array}$ \\
\hline $\begin{array}{l}\text { The Cochrane Library } \\
\text { (searched on } 2 / 8 / 2018 \\
\text { and } 2 / 10 / 2019 \text { ) }\end{array}$ & $\begin{array}{l}\text { \#1. (Herbal supplement or dietary supplement }{ }^{*} \text { or nutraceutical }{ }^{*} \text { or vitamin }{ }^{*} \text { or multivitamin* or perilla } \\
\text { oil or longovital or camel thorn or zinc sulphate or beta-glucan or bee-propolis or plant extract }{ }^{*} \text { or } \\
\text { chinese herbal or honey or complementary therapies or aloe vera or myrrh or medicinal plant } \\
\text { \#2. (Recurrent aphthous stomatitis or recurrent aphthous ulcer }{ }^{*} \text { ) } \\
\# 3 \text {. \#1 and \#2 }\end{array}$ \\
\hline $\begin{array}{l}\text { EMBASE } \\
\text { (searched on } 2 / 8 / 2018 \\
\text { and } 2 / 10 / 2019 \text { ) }\end{array}$ & $\begin{array}{l}\text { \#1. 'Herbaceous agent' or 'nutraceutical' or 'dietary supplement' or 'chinese drug' or 'chinese } \\
\text { herb' or 'vitamin' or 'plant extract' or 'alternative medicine' or 'medicinal plant' or (perilla and oil) or } \\
\text { logovital or (camel and thorn) or (zinc and sulphate) or 'beta glucan' or 'bee propolis' or honey or } \\
\text { (aloe and vera) or myrrh } \\
\text { \#2. 'aphthous stomatitis' } \\
\text { \#3. \#1 and \#2 } \\
\text { \#4. \#3 and ('clinical trial'/de or 'controlled clinical trial'/de or 'double blind procedure'/de or 'evidence } \\
\text { based medicine'/de or 'major clinical study'/de or 'randomized controlled trial'/de or 'randomized } \\
\text { controlled trial (topic)'/de or 'systematic review'/de) }\end{array}$ \\
\hline
\end{tabular}

Supplement Table 2: Summary of risk of bias for eligible RCT studies.

\begin{tabular}{|c|c|c|c|c|c|c|c|}
\hline Study & $\begin{array}{l}\text { Random } \\
\text { seq. } \\
\text { generation }\end{array}$ & $\begin{array}{l}\text { Allocation } \\
\text { concealment }\end{array}$ & Blinding & $\begin{array}{l}\text { Incomplete } \\
\text { outcome } \\
\text { data }\end{array}$ & $\begin{array}{l}\text { Selective } \\
\text { reporting }\end{array}$ & $\begin{array}{l}\text { Other } \\
\text { potential } \\
\text { bias }\end{array}$ & $\begin{array}{l}\text { Overall } \\
\text { bias }\end{array}$ \\
\hline Amanlou, et al. [11] & $?$ & $?$ & $?$ & $?$ & - & - & $?$ \\
\hline A Stojanovska, et al. [13] & $?$ & $?$ & $?$ & + & - & $?$ & + \\
\hline Babaee, et al. [14] & $?$ & - & - & $?$ & - & $?$ & $?$ \\
\hline Babaee, et al. [15] & $?$ & $?$ & $?$ & - & - & $?$ & $?$ \\
\hline El-Haddad, et al. [16] & - & - & + & + & - & $?$ & + \\
\hline Hoseinpour, et al. [17] & - & - & - & - & - & - & - \\
\hline Jiang, et al. [10] & - & - & $?$ & $?$ & - & $?$ & $?$ \\
\hline Liu, et al. [18] & - & - & $?$ & - & - & $?$ & $?$ \\
\hline Mansour, et al. [19] & - & $?$ & $?$ & - & - & - & $?$ \\
\hline Pourahmad, et al. [20] & $?$ & - & $?$ & $?$ & - & - & $?$ \\
\hline Yang, et al. [12] & - & $?$ & $?$ & - & - & $?$ & $?$ \\
\hline
\end{tabular}

Key: - low; + high risk; ? unclear. 